\title{
Ecosystem Variability in West Greenland Waters
}

\author{
Erik Buch \\ Danish Meteorological Institute \\ Lyngbyvej 100, DK-2100 Copenhagen, Denmark \\ Søren Anker Pedersen \\ Greenland Institute of Natural Resources and Danish Fisheries Research \\ Kavalergaarden 6, DK-2920 Charlottenlund, Denmark \\ Mads Hvid Ribergaard \\ Danish Meteorological Institute and Greenland Institute of Natural Resources \\ Lyngbyvej 100, DK-2100 Copenhagen, Denmark
}

Buch, E., S. A. Pedersen, and M. H. Ribergaard. 2004. Ecosystem Variability in West Greenland Waters J. Northw. Atl. Fish. Sci., 34: 13-28. doi:10.2960/J.v34.m479

\begin{abstract}
A review of the climate conditions off West Greenland during the past 50 years shows large variability in the atmospheric, oceanographic and sea-ice variables, as well as in fish stocks. A positive relationship is found between water temperature and the recruitment of cod and redfish, whereas the recruitment of shrimp and halibut is negatively related to temperature. Observed shifts in the hydrographic conditions during the second half of the 1990s indicate that some changes in the environment may be expected in the coming years. Relationships between the past variations in fish resources, hydrographic conditions, and the large-scale climatic conditions, as expressed by the North Atlantic Oscillation (NAO), strongly support the incorporation of environmental variability into prediction models for fish recruitment and therefore into the assessment of the fish resources.

Key words: biomass, climate, cod, fishery, West Greenland, salinity, shrimp, temperature, variability, NAO
\end{abstract}

\section{Introduction}

In the $20^{\text {th }}$ century Greenland experienced two great transitions, the first from seal hunting to a cod fishery, and then from cod to a shrimp fishery. Both affected the human population centres and the economy of West Greenland (Hamilton et al., 2000). The economic transitions reflected large-scale shifts in the underlying marine ecosystems, driven by interactions between climate and human resource use.

The marine shelf ecosystems off East and West Greenland are intermediate between the cold Polar water masses of the Arctic region and temperate water masses of the Atlantic Ocean. They are important fishing grounds and are characterized by relatively few dominant species, which interact strongly (Pedersen and Kanneworff, 1995; Rätz and Stransky, MS 1999; Pedersen and Zeller, 2001). Ocean currents, that transport water from the polar and temperate regions, affect the marine productivity on the Greenland shelves and changes in the North Atlantic circulation system therefore have major impacts on the distribution of fish species and fishery yields (Pedersen and Smidt, 2000; Pedersen and Rice, 2002).
Greenland climate has undergone some dramatic changes through the $20^{\text {th }}$ century. The period $1920-70$ generally experienced warm air temperatures while the subsequent 30 years have been dominated by three extreme cold periods around 1970, the early 1980s and the early 1990s. These atmospheric changes have also been reflected in the oceanographic conditions of the Greenland waters (Buch, $2000 \mathrm{a}, \mathrm{b}$ ).

In the present paper we describe recent developments in the fishery, the atmospheric climate and ocean hydrography off the West Greenland and discuss possible relationships between climate variability and the fish stocks.

\section{Data}

The fisheries and fish stock data have been retrieved from a number of assessment documents available from the Northwest Atlantic Fisheries Organization (NAFO; $w w w$. nafo.int), the International Council for the Exploration of the Seas (ICES; MS 2000), and the Greenland Institute of Natural Resources.

The Greenland Fisheries Research Institute (GFRI), since it was founded in 1947, has tried to occupy all the 
NAFO (formerly, the International Commission for North Atlantic Fisheries (ICNAF)) standard sections (Fig.1) along the west coast of Greenland at least once per year and the Fylla Bank section several times per year. All sections north of the Fylla Bank section have generally been covered twice a year (June-July and November) while the southernmost sections have been occupied only once (March-April). In 1990, the oceanographic activity was reduced due to reorganisation of the GFRI, resulting in the standard sections being cancelled in 1991. From 1992 to 1997 , one annual survey to the NAFO standard sections was performed by the Royal Danish Administration of Navigation and Hydrography on contract to the Greenland Fisheries Research Institute, and since 1998 the Danish Meteorological Institute (DMI) has undertaken this task. In addition, oceanographic observations have been carried out during the fish trawl surveys.

The DMI has obtained meteorological observations in Greenland since 1873 and, for almost the same period, has collected information on the distribution of sea ice in Greenland waters.
Atmospheric sea level pressures from Ponta Delgada, in the Azores, and Reykjavik, Iceland, were obtained from the Climate Research Unit (www.cru.uea.ac.uk/cru/data/ nao.htm) and updated to 2002. For a description of these data see Jones et al. (1997) and Jones (1984).

\section{Biological Variability}

A rich Atlantic cod (Gadus morhua) fishery started off West Greenland in the 1920s after a general warming of the Northern Hemisphere (Jensen, 1939; Dickson et al., 1994; Buch et al., 1994; Horsted, 2000). The West Greenland cod fishery peaked in the 1960s at annual catches between 400000 and 500000 tons. During the late 1960 s, the cod catches declined drastically along with the catches of other commercially important fish species, including redfish (Sebastes marinus and S. mentella), Atlantic halibut (Hippoglossus hippoglossus) and wolfish (Atlantic wolfish, Anarhichas lupus, and spotted wolfish, Anarhichas minor), that were mainly taken as by-catch in the cod fishery. After 1969, catches of cod and redfish fluctuated around a much lower mean level (Fig. 2).

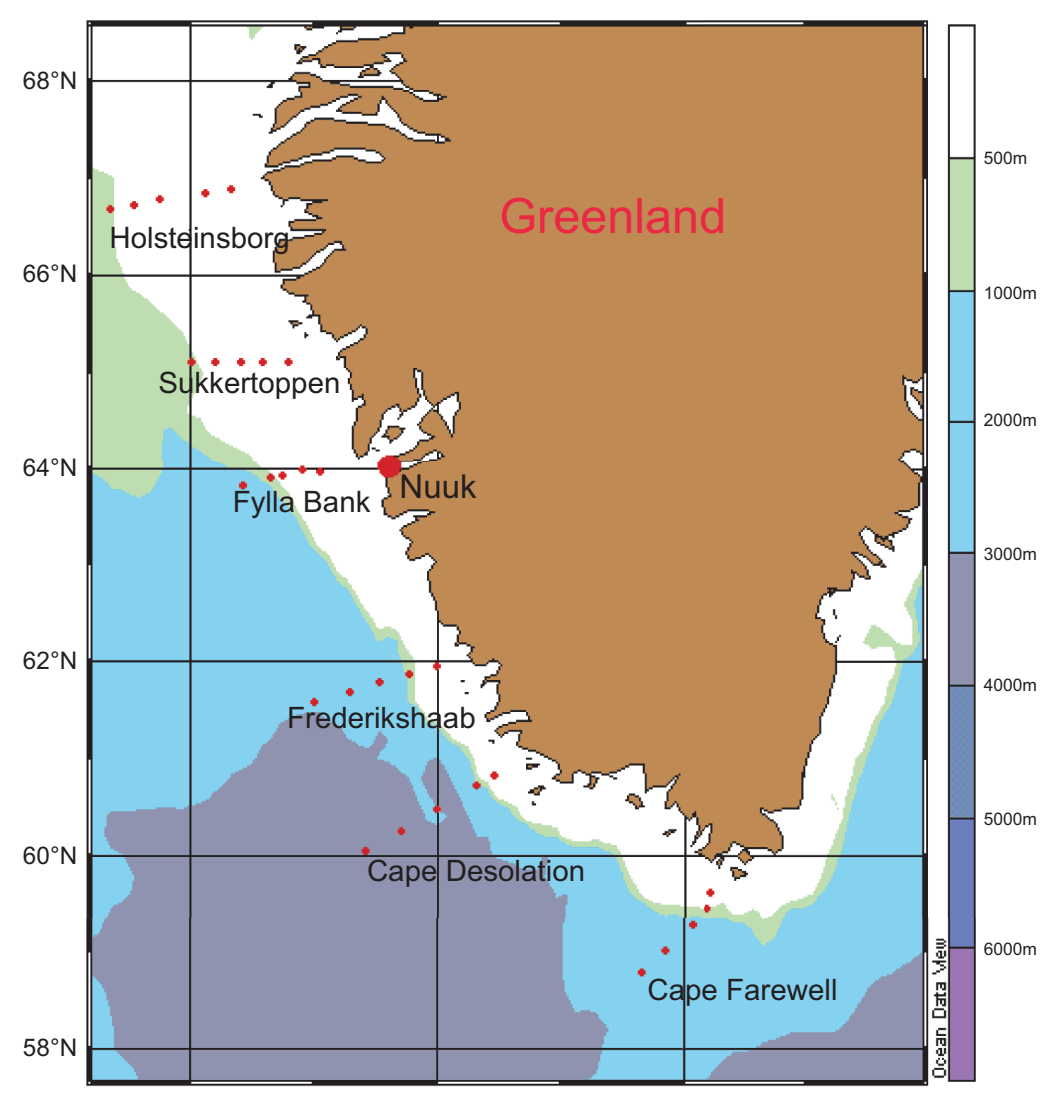

Fig. 1. NAFO standard oceanographic sections off West Greenland. Note that for each section Station 1 is closest to land. 

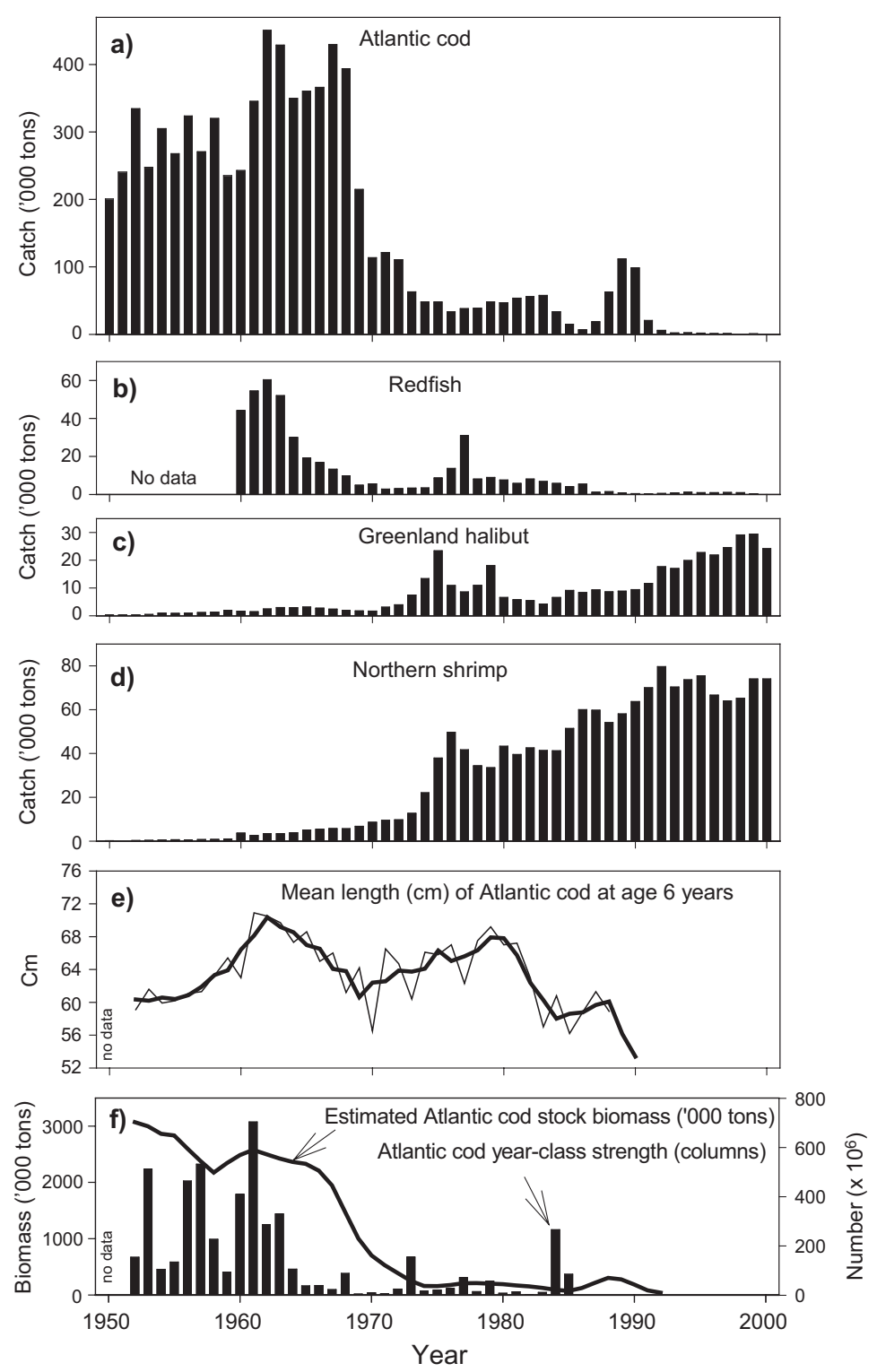

Fig. 2. (a-d) Annual catches of four important commercial fish species off West Greenland (NAFO Subarea 1, inshore and offshore combined). (e) Mean length-at-age 6 of cod (heavy line is the 3-year running mean). (f) Estimated stock biomass and year-class strength of West Greenland cod. Data from: (a-d) Horsted (2000), NAFO Scientific Council Meeting Reports and Documents for 2001; (e) Riget and Engelstoft (1998); (f) ICES (MS 1996, 2000).

Except for a temporary improvement of cod during 1988-90 due to a strong 1984 year-class recruited from Iceland, annual groundfish surveys on the West Greenland Shelf (0-400 $\mathrm{m}$ depth), undertaken by Germany since 1982, show a dramatic decline in overall biomass and mean individual weight of the demersal fishes (Rätz and Stransky, MS 1999.
The decline in the cod catches is believed, in large part, to be a response to climate variability. Climate is thought to have led to both the center of the cod fishery moving south during the 1980s and the decrease in sizeat-age (Hovgård and Buch, 1990; Riget and Engelstoft, 1998; Rätz et al., 1999; Horsted, 2000). At the same time catches of two other commercially important species, 
northern shrimp (Pandalus borealis) and Greenland halibut (Reinhardtius hippoglossoides) increased (Fig. 2). In recent years a new fishery for snow crab (Chionoectes opilio) shows a steep increasing trend from a few hundred tons in 1994 to 15000 tons in 2001.

During the last two decades, northern shrimp has been the most important fishery resource in Greenland by far. Export of shrimp to Japan, has provided a high-value economic alternative to cod, and by 1995 comprised $73 \%$ of Greenland's total exports. The shrimp stock off West Greenland is distributed in NAFO Div. 0A and Subarea 1 (see Fig. 3). There is no evidence of distinct subpopulations and the entire shrimp stock is assessed as a single population. The Greenland fishery exploits the stock in Subarea 1 (Div. 1A to 1F) in offshore and inshore areas (primarily Disko Bay) (Fig. 3). Overall shrimp catches increased until 1992, varied at lower levels from 1993 to 1997 and increased thereafter (see Fig. 2).

From 1975 to 1984 the annual effort in the shrimp fishery showed a slightly increasing trend from about 75 $000 \mathrm{hr}$ to about $93000 \mathrm{hr}$ of fishing. In subsequent years the offshore fleet increased and effort rose to $250000 \mathrm{hr}$ in 1991-92 (Fig. 4). Thereafter effort decreased as a result of management measures, reduced activity in Div. 0A and a higher fishing efficiency of the participating vessels.

The catch-per-unit-effort (CPUE) for the West Greenland shrimp fishery can be used as a stock biomass index (Fig. 4). The spike in 1987 is likely the result of some very strong year-classes produced in the early 1980s. From 1990 to 2000 the CPUE index has shown an increasing trend suggesting an increasing shrimp stock biomass (Fig. 4).

The GFRI has conducted annual stratified-random shrimp trawl surveys since 1988 in the main West Greenland shrimp distribution area (Carlsson and Kanneworff, MS 2000). For the period 1988-97, biomass indices of the fishable shrimp stock in the offshore areas were stable at a level of about 250000 tons (Fig. 5a). From 1998 the biomass indices show a significant increase to a record high biomass estimate in 2000 of 350000 tons.

A change in geographical distribution of the commercial fishing effort for shrimp has been observed since the late 1980s (Hvingel, MS 2000). Initially, Div. $1 \mathrm{~A}$ and $1 \mathrm{~B}$ contained the most important fishing grounds, but from the late 1980s the fishery has gradually moved southward as indicated by the mean latitude of effort allocation (Fig. 5b). At the same time, the highest shrimp catches in the annual shrimp survey showed a movement towards shallower depths (Fig. 5c). The change in shrimp catch distributions both geographically and in depth observed during the survey period may indicate stock migration towards preferable temperature habitat due to the lower temperatures in the late-1980s and early-1990s (described in a later section). However, from 1995 to 1999 , the average bottom temperature during the shrimp survey (July-August) showed a clear increasing trend (Fig. 5d) and this has not yet resulted in a movement of the center of the main fishing effort northward again (Fig. 5b).

During the 1990s there was a slight increase in catches of striped pink shrimp (Pandalus montagui) in local commercial fishing areas and during the annual shrimp survey (Fig. 5e). This shrimp species is well adapted to cold conditions and the increased catches may indicate a positive biological effect on this species of the cold sea climate from the late 1980s to the mid-1990s. The peaks in the abundance indices from the shrimp survey in 1995 and 1998 are unexplained (Kanneworff, MS 2000), but a lag between increased larval production and recruitment to the catchable stock should be expected.

From 1950 to 1984 , GFRI annually collected zooplankton samples from West Greenland waters. The zooplankton displacement volume and most of the zooplankton taxa showed higher abundance indices in the generally warmer period 1950-68 compared to the colder period 1969-84 (Pedersen and Smidt, 2000). However, abundance indices of sandeel larvae were negatively correlated with sea temperature. Historical sandeel and shrimp larvae abundance indices (1950-84, in Pedersen and Rice, 2002), updated with abundance indices from zooplankton samples collected in 1996, 1999 and 2000, showed similar trends (Fig. 6) and are positively correlated $(r=0.48, p<0.05, n=23$; Spearmann rank correlation).

\section{Climate Variability}

Over the last fifty years of the $20^{\text {th }}$ century, the West Greenland area has experienced some rather dramatic fluctuations in climate, which have influenced the living conditions for all species on land, as well as in the ocean. These fluctuations may therefore be regarded as one of the reasons for the observed variability in the various fish stocks described in the previous section.

\section{Atmospheric conditions}

Over the past decade, several papers have dealt with the importance of the North Atlantic Oscillation (NAO) Index on the climate in the North Atlantic region (Dickson et al., 2000; Blindheim et al., 2000; Dickson et al., 1996; 


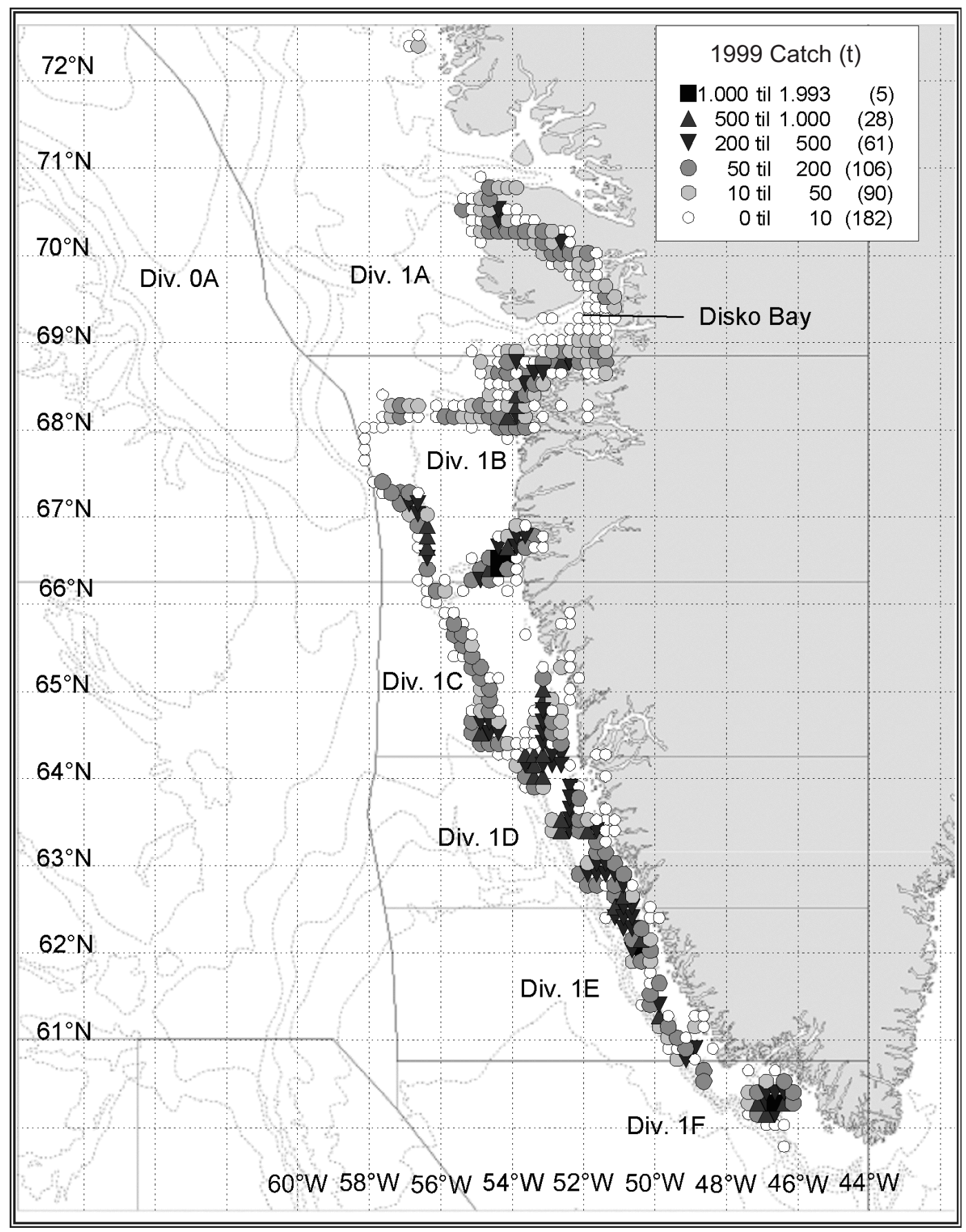

Fig. 3. Spatial distribution of the Greenland commercial shrimp catches in NAFO Subarea 1 (Div. A-F) in 1999 from Hvingel (2000).

Seager et al., 2002) and thereby also in the West Greenland area (Buch, 2000b). The NAO, which is associated with changes in the surface westerlies across the Atlantic onto Europe, refers to a meridional oscillation in the atmospheric mass with centres of action near the Iceland Low and the Azores High (van Loon and Rogers, 1978). Because the signature of the NAO is strongly regional, a simple index of NAO was defined as the difference between the normalised SLP anomalies at the Azores and Iceland (detailed discussion about the historical literature can be found in van Loon and Rogers, 1978). In order to extend the NAO index back in time, measurements from Lisbon or Gibraltar are commonly used instead of the Azores (e.g. Hurrell, 1995 and Jones et al., 1997). 


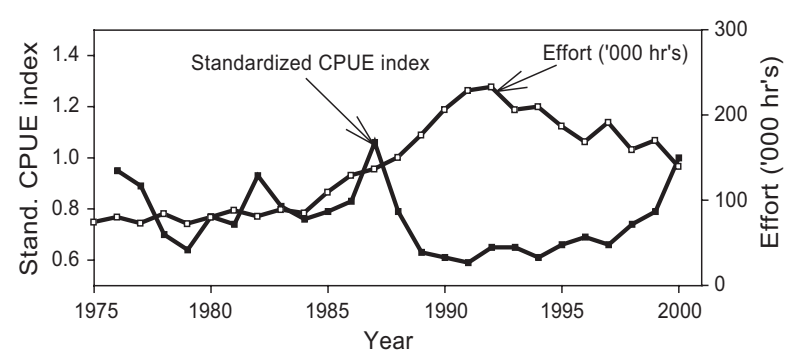

Fig. 4. Effort and standardized CPUE index of the West Greenland shrimp fishery, 1975-2000. Data from Siegstad (2000).

Although the NAO signal is evident throughout the year, it is most pronounced during winter and accounts for more than one-third of the total variance of the Sea Level Pressure (SLP) field over the North Atlantic (references in Hurrell, 1995). We use wintertime (December-March) SLP difference between Ponta Delgada, Azores, and Reykjavik, Iceland, and subtract the mean SLP difference for the period 1961-90 to construct the NAO anomaly.

The variability of the NAO index since 1865 is shown in Fig. 7, where the heavy solid line represents the lowpass filtered meridional pressure gradient. Positive values of the index indicate stronger than average westerlies over the mid-latitudes associated with low-pressure anomalies over the region of the Icelandic Low and anomalous high pressures across the subtropical Atlantic.

In addition to a large amount of interannual variability, there have been several periods when the NAO index persisted in one phase for many winters, (van Loon and Rogers, 1978, Barnett 1985, Hurrell and van Loon, 1997). Over the region of the Icelandic Low, the seasonal pressures were anomalously low during winter from the turn of the century until about 1930 (with exception of the 1916-19 winters), while pressures were higher than average at lower latitudes. Consequently, the wind over Europe had a strong westerly component and the moderating influence of the ocean contributed to higher than normal temperatures over much of Europe (Parker and Folland, 1988). From the early 1940s until the early 1970s, the NAO index exhibited a downward trend into the extreme low NAO of the sixties and this period was marked by European wintertime temperatures that were frequently lower than normal (van Loon and Williams, 1976, Moses et al., 1987). A sharp reversal occurred after the early-1970s and, since the 1980s, the NAO has remained in a highly positive phase with SLP anomalies of more than $10 \mathrm{hPa}$ in magnitude over both the subpolar and the subtropical Atlantic. The 1989, 1990, 1994 and 1995 winters were marked by some of the highest positive values of the NAO index recorded since 1865 (Fig. 7).
A detailed analysis by Hurrell and van Loon (1997) suggests that the temperature anomalies for the North Atlantic and surrounding land masses for the 1980-94 period are strongly related to the persistent and exceptionally strong positive phase of the NAO index (their Fig. 1a is reproduced in Fig. 8 using NCEP/NCAR reanalysis data). This clearly illustrates a strong correlation between the strength of the westerlies across the North Atlantic - (the NAO index) and the air temperatures in Greenland and Europe. It also shows that the air temperatures in Greenland and Europe are negatively correlated, a phenomenon referred to as a seesaw effect (e.g. van Loon and Rogers, 1978).

This can be illustrated further by comparing the temperatures over Greenland from a low NAO period (1960-69) to a high NAO period (1990-99) (Fig. 9). Note that especially offshore of West Greenland, it was significantly warmer in the 1960s than in the 1990s.

A time series of annual mean air temperatures from Nuuk, West Greenland for the period 1873-2002 is shown in Fig. 10. In addition to the interannual variability, it reflects the general picture of variability outlined above in the description of the NAO index (Fig.7), i.e. high NAO conditions are normally reflected in cold conditions in Greenland (Fig. 9). The late-1990s are, however, an exception from this pattern, since both NAO and Nuuk air temperatures show relatively high values. This was due to a slight displacement of the NAO pattern towards the east or northeast (ICES, 2000, 2001, 2002).

A detailed analysis using $6 \mathrm{hr}$ winds from a number of observation sites in Greenland show that the changes in the wind pattern in the Greenland area are generally minor, in large part because of the dominating influence by the local orography.

\section{Hydrographic conditions}

The waters off West Greenland are dominated by water masses advected into the region from outside (Buch, 2000a,b):

- In the surface layer close to the coast, cold and low saline Polar Water originates from the East Greenland Current.

- Water below and to the west of the Polar Water derives from the North Atlantic Current.

The changes in the atmospheric conditions caused by the shift from low NAO to high NAO conditions affect the ocean circulation and ocean conditions in the North Atlantic (Dickson et al, 1996, Dickson et al., 2000). The 

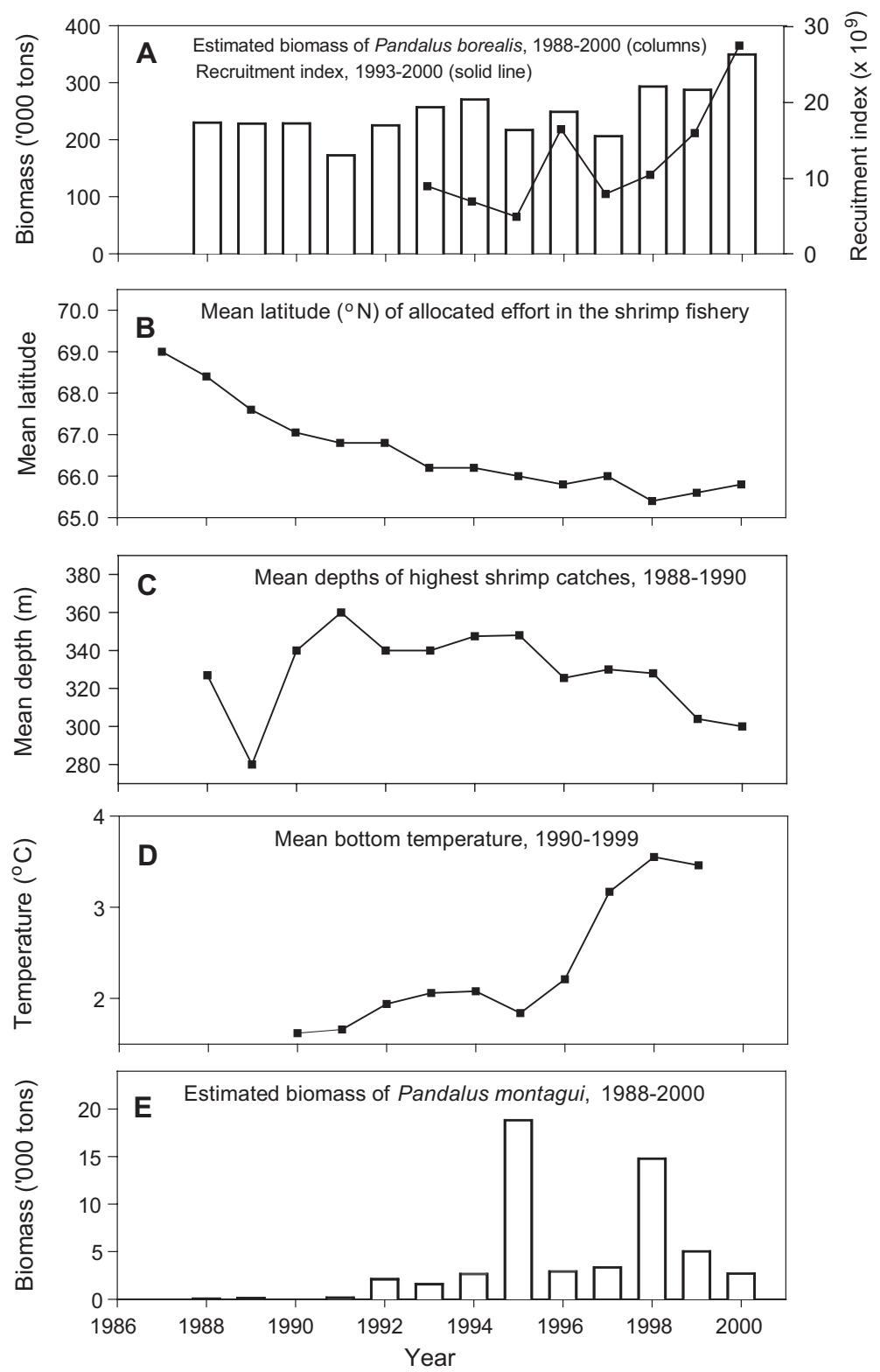

Fig. 5. (a) Northern shrimp biomass indices from the annual shrimp survey and (b) the mean latitude of the effort in the commercial fishery. (c) Mean depths of highest shrimp catches and (d) mean bottom temperature during the survey. (e) The annual biomass indices of Pandalus montagui during the survey. Data from (a-b) Siegstad (MS 2000); (c) Carlsson and Kanneworff (MS 2000); (d) Carlsson and Kanneworff (MS1999); (e) Kanneworff (MS 2000).

oceanographic conditions off West Greenland are also directly and indirectly affected by climate variability related to the changes in NAO.

The most well-known oceanographic time series from West Greenland is the mid-June mean temperature on top of Fylla Bank (Station 2, 0-40 m; Fig. 11), which the GFRI has maintained due to its importance to the cod stock assessment. These temperatures can vary quite drastically from one year to the next, often more than $1^{\circ} \mathrm{C}$, reflecting the variability of both the atmospheric influence and the inflow of Polar Water. The 3-year running means naturally smooth out the high-frequency variations and better reflect the large-scale climatic variability. 


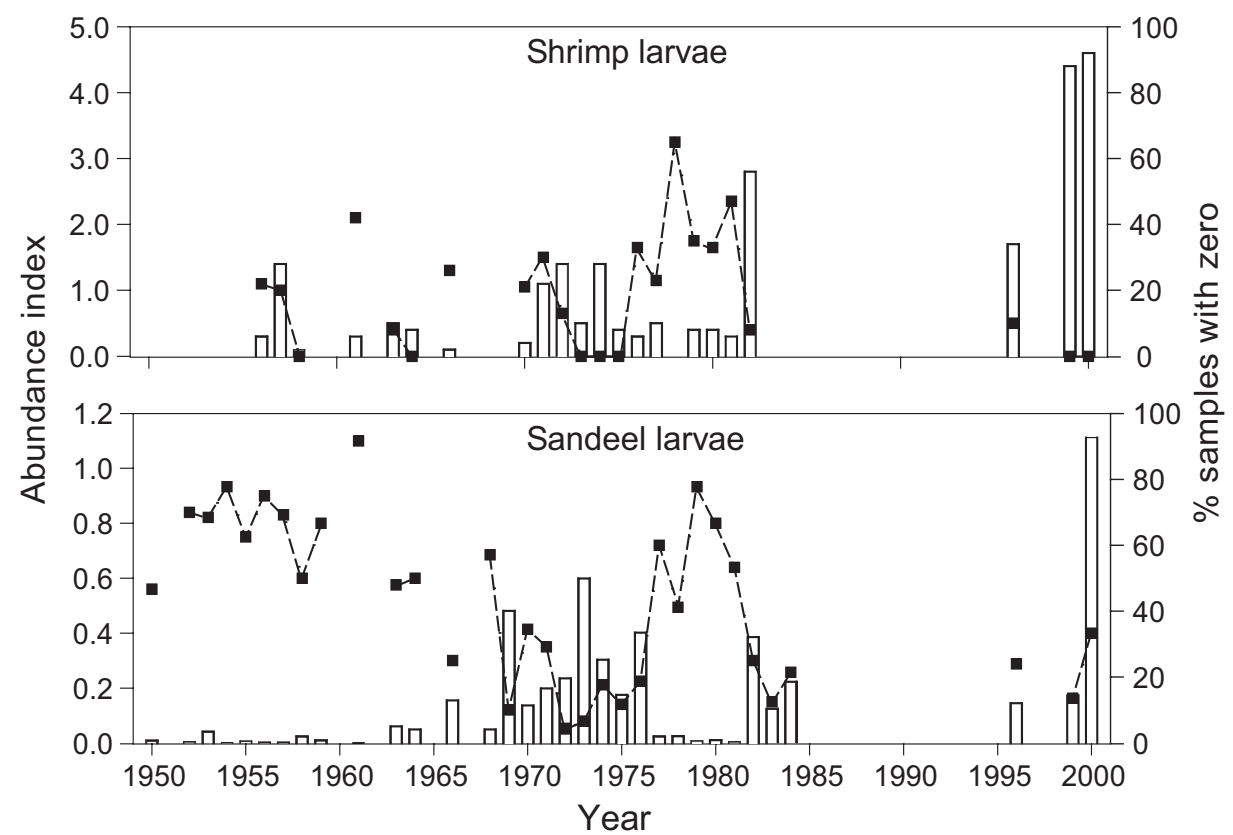

Fig. 6. Shrimp and sandeel larvae abundance indices (columns) and percentage of samples with zero catch (squares), 1950-2000. Years with data are indicated by the squares.

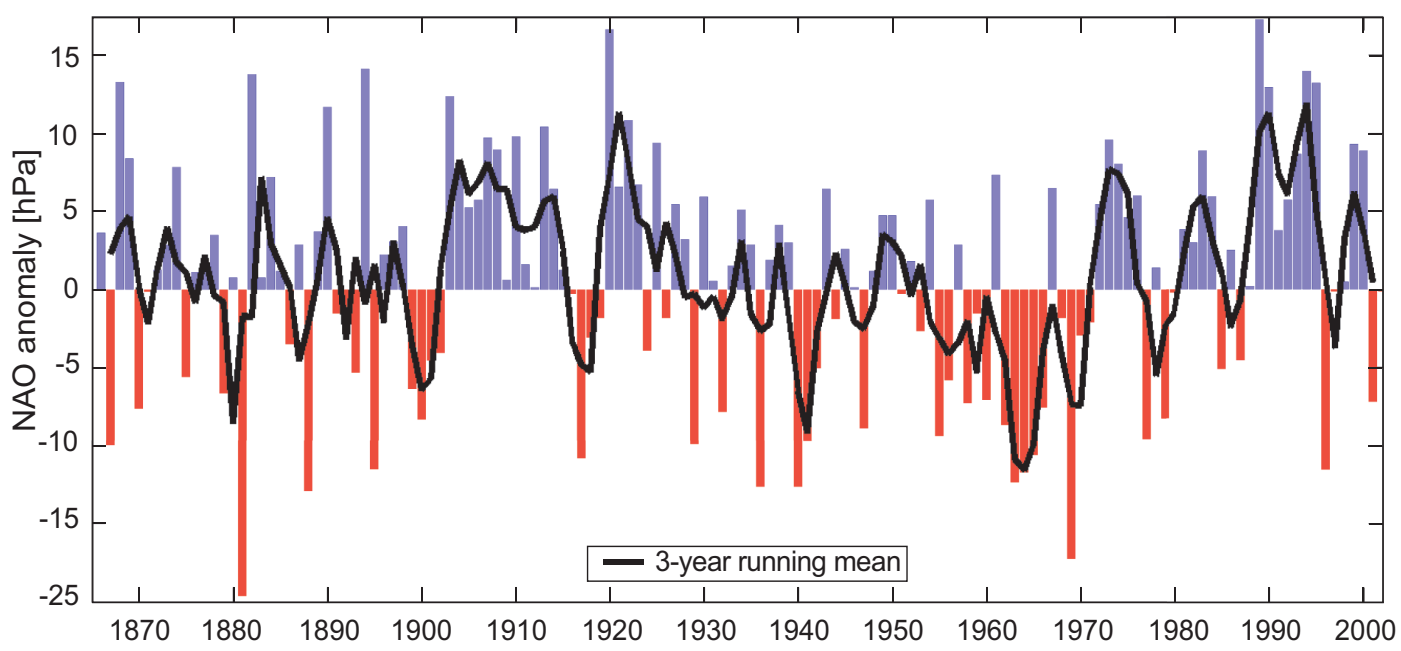

Fig. 7. Time series of the winter (December-March) index of the NAO (as defined in the text) from 1865-2002. The heavy solid line represents the meridional pressure gradient smoothed with a 3-year running mean filter (data updated from www.cru.uea.ac.uk/cru/data/nao.htm).

The 50-year temperature time series reveal some very distinct climatic events:

- The 1950-68 period generally showed high temperatures around $2^{\circ} \mathrm{C}$.

- Around 1970 the coldest period was experienced. The cold temperatures of this period were due to an anomalous high inflow of Polar Water, which was closely linked to the "Great Salinity Anomaly"
(Dickson et al., 1988, Belkin et al., 1998). At the same time, the NAO index changed from negative to positive causing a shift from warm to cold atmospheric conditions off West Greenland.

- In the early 1980s and early 1990s two extremely cold periods were observed reflecting the cold atmospheric conditions associated with the high NAO indices during these years. 
- Low ocean temperatures were observed in 1997 although the atmospheric conditions were quite warm. Together with low salinity measurements (Fig. 10) they suggest a high inflow of Polar Water.

- During the late-1990s, temperatures have been rather high despite high NAO values. This was due to a displacement of the NAO pattern towards the east or northeast (ICES, 2000, 2001, 2002).

Figure 12 shows the time-series of the mid-June salinity observed on top of Fylla Bank. The "Great Salinity Anomaly" around 1970 is clearly evident in this data set, as well as in the temperature data (Fig. 11). The cold ocean temperatures in the early-1980s and early-1990s are not reflected in the surface salinities at Fylla Bank supporting that these cold periods were due to atmospheric cooling. Relatively low salinities were observed in 1996 and 1997 indicating that the inflow of Polar Water was above normal in these two years and most likely contributed to the lower temperatures as well.
At greater depth, there are three water masses of Atlantic origin (Buch, 2000b):

- Irminger Water - temperature around $4.5^{\circ} \mathrm{C}$ and salinity above 34.95 .

- Irminger Mode Water - Irminger Water mixes with surrounding water masses on its way towards southwest Greenland - temperature around $4^{\circ} \mathrm{C}$ and salinities between 34.85 and 34.95 .

- Northwest Atlantic Mode Water - temperature above $2^{\circ} \mathrm{C}$ and salinities between 34.5 and 34.85 . In late autumn, the temperature rises to above $5^{\circ} \mathrm{C}$.

Time series plots of temperature and salinity from stations just west of the shelf along the Cape Farewell and Fylla Bank sections are shown in Fig. 13. Changes in the inflow of water of Atlantic origin can be seen. Before the 1970s, pure Irminger Water $(S>34.95)$ was present at the Cape Farewell Station 3 in large quantities at depths greater than 100-400 m, although the inflow appeared to

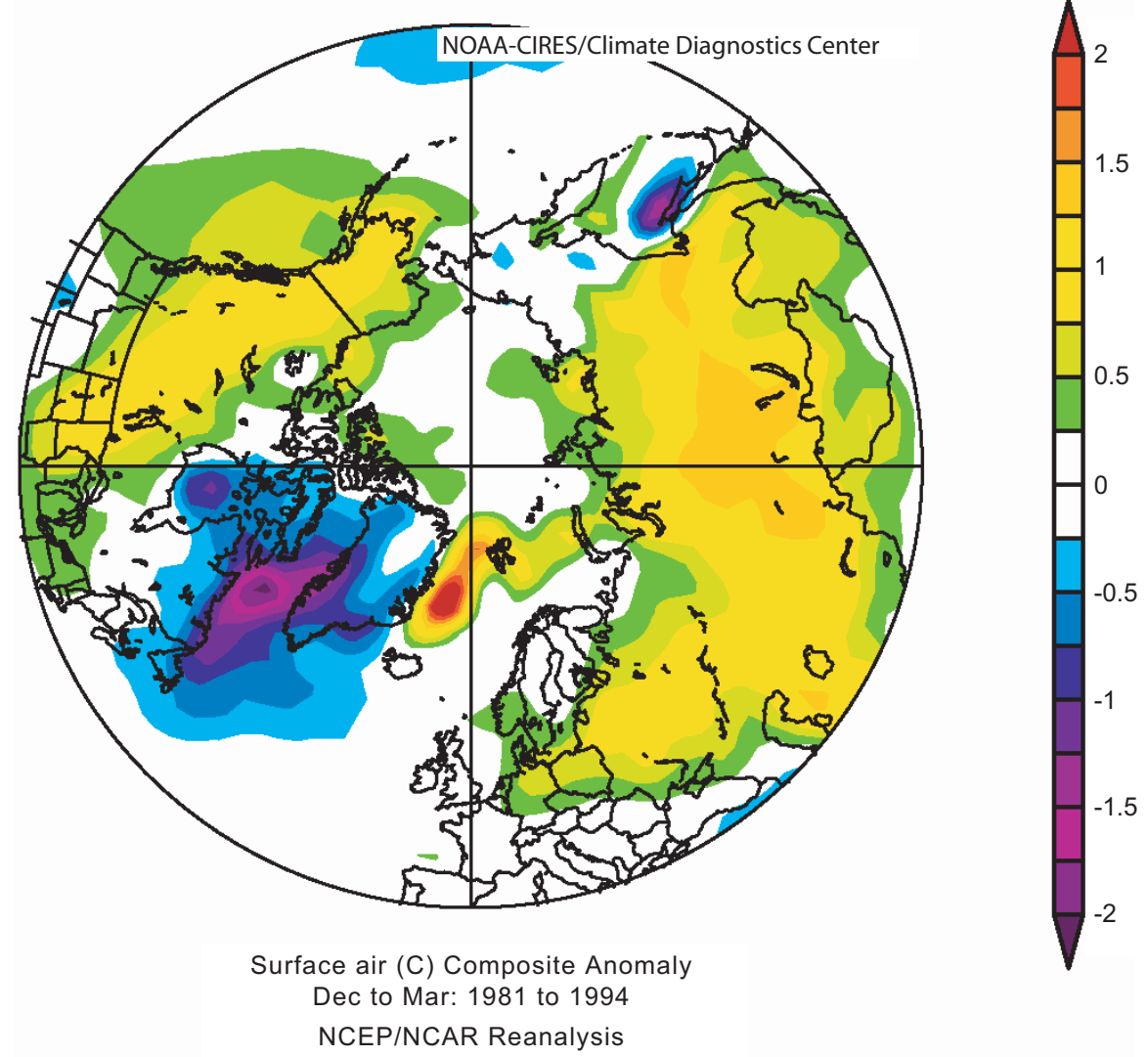

Fig. 8. Fourteen winters (December-March, 1981-94) average surface temperature anomalies relative to the period 1968-96 calculated using the NCEP/NCAR reanalysis database. (www.cdc.noaa.gov). 

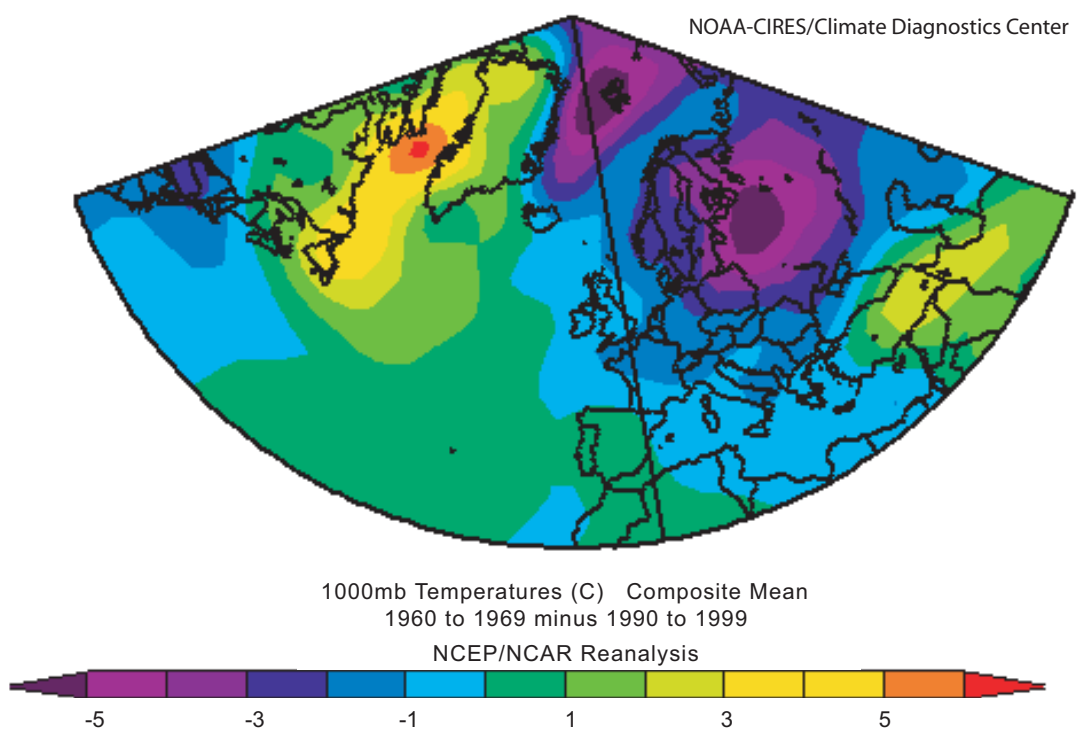

Fig. 9. Difference in air temperatures at the $1000 \mathrm{hPa}$ level between 1960-69 and 1990-90 calculated using the NCEP/NCAR reanalysis database (www.cdc. noaa.gov).

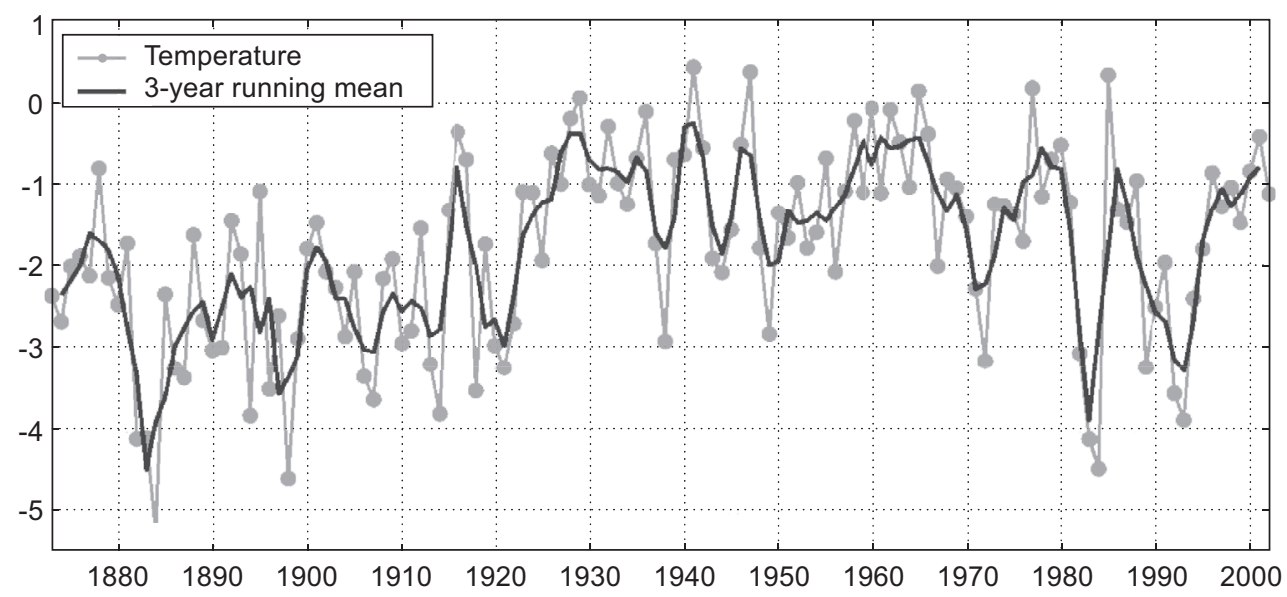

Fig. 10. Annual mean air temperatures at Nuuk, 1873-2002. The red curve represents a 3-year running mean. See Fig. 1 for location.

be gradually decreasing. The heat content was markedly greater at that time with temperatures above $4.5^{\circ} \mathrm{C}$ in most of the upper $600 \mathrm{~m}$ of the water column, with the upper $200 \mathrm{~m}$ having temperatures above $5.5^{\circ} \mathrm{C}$. The dominant water mass between 1970-95 seems to be the Irminger Mode Water; however, note that no data were available from the mid-1970s to the early-1990s. From 1995, Irminger Water is again observed but in smaller quantities than prior to 1970 . The apparent increased activity in the circulation of Irminger Water after 1995 relative to previous years was also observed in the interior of the Irminger Sea (Mortensen and Valdimarsson, 1999).
At Fylla Bank Station 4, there is a similar apparent reduction in the inflow of salt and heat. The Irminger Mode Water was present in much higher quantities before the mid-1970s than after, and the three cold periods are clearly reflected in the temperatures of the upper $200 \mathrm{~m}$. A weak freshening in the upper $150-200 \mathrm{~m}$ is observed since 1965, resulting in a less dense water mass within this layer. This freshening, however, is most dominant in the upper $50-100 \mathrm{~m}$. A similar freshening during the same period was also observed in the Irminger Water component north of Iceland (Malmberg, 1985), indicating a reduction of the strength of the Irminger Current after 


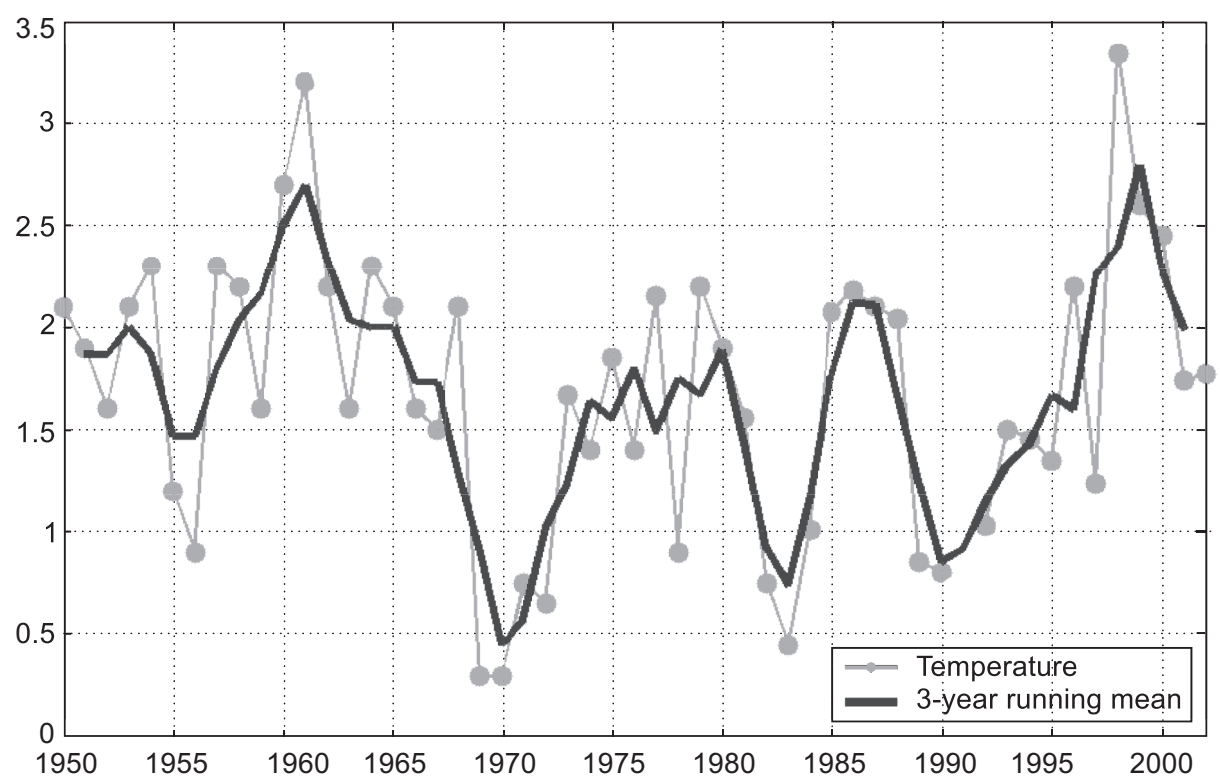

Fig. 11. Mean sea temperatures of the upper $40 \mathrm{~m}$ on Fylla Bank Station 2, mid-June, 1950-2002.

1965 and/or a more dominant influence of Polar Water. From the mid-1960s to the early-1970s, the freshening was caused by an anomalous high inflow of Polar Water closely linked to the "Great Salinity Anomaly", whereas afterwards it is believed to be caused by a high NAO anomaly reducing the strength of the Irminger Current by the increased windstress forcing of the North Atlantic Current eastward.

\section{Ice conditions}

Two main types of sea ice dominate in West Greenland waters:

1. "Storis", or multiyear ice of polar origin carried to southwest Greenland by the East Greenland Current, and

2. "Westice", or first-year ice formed in Baffin Bay and Davis Strait.

The southwest Greenland waters, primarily the Julianehaab Bight, are covered with "Storis" 8-9 months of the year. The leading edge of the "Storis" normally passes Cape Farewell in December or January, but the timing can vary from year to year by several months. The amount of "Storis" entering southwest Greenland waters show great interannual variability and is governed by several factors such as the outflow of sea ice from the Arctic Ocean, the formation of sea ice in the Greenland Sea, and wind conditions in the Greenland, Iceland and the Irminger seas. Extremely large amounts of "Storis" entered southwest Greenland waters in 1968-70, 1982, 1984, 1989, 1990 and 1993 (Keld Q. Hansen, Greenland Ice Service, pers. comm.).

The formation of "Westice" starts in northern Baffin Bay in September and in the succeeding months it spreads along the northwest Greenland coast. In most years the ice limit reaches Aasiat (southern entrance to Disko Bay) in December or January. The waters of southwest Greenland are normally not affected by "Westice" because the inflow of warm water of Atlantic origin has its maximum during autumn and early winter (Buch, 2000a).

The presence of extremely cold air masses over the Davis Strait in 1983-84 and 1989-94 (Fig. 14) resulted in the formation of extraordinary large amounts of "Westice", which moved so far south it resulted in the unusual situation that the "Westice" and the "Storis" met in the vicinity of Julianehaab Bight. This occurred several times during these periods.

\section{Discussion}

The shift in community structure and landing composition of fish in Greenland during the second half of the $20^{\text {th }}$ century coincides in time with the large climatic changes observed in the Greenland area. It is therefore believed that the observed changes in recruitment patterns are largely driven by changes in ocean climate. In terms of mechanisms linking oceanographic factors to recruitment 


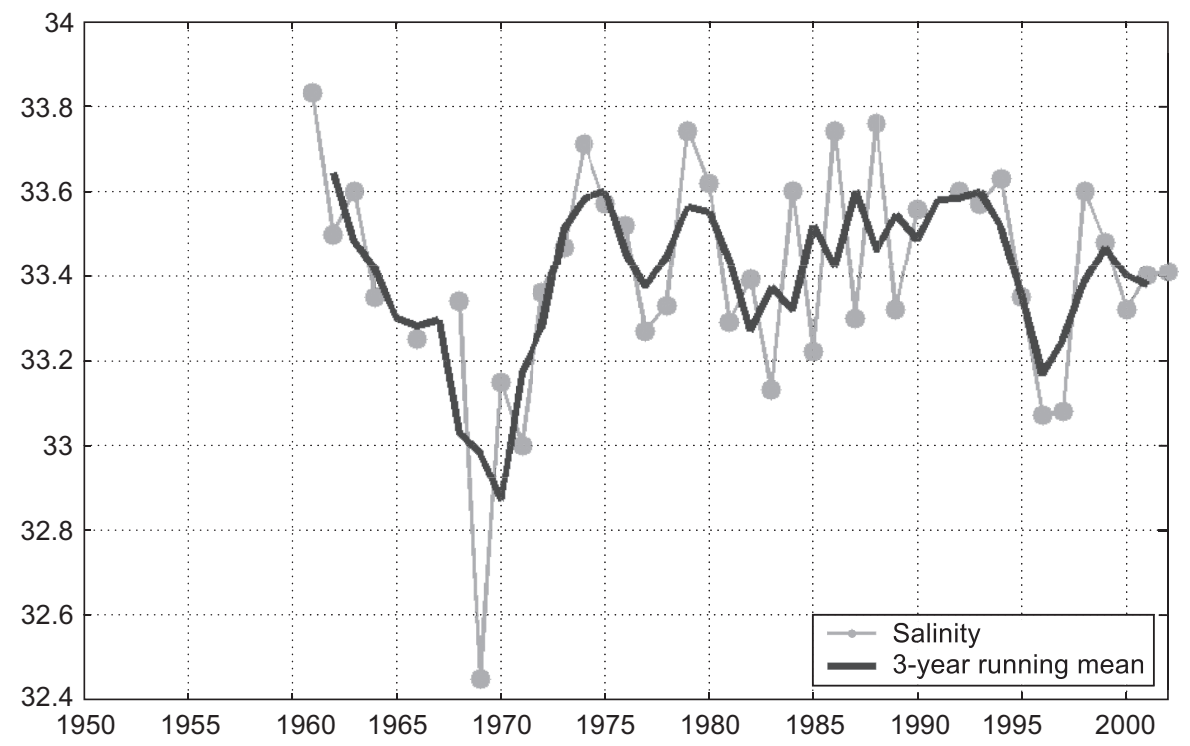

Fig. 12. Mean salinity of the upper $40 \mathrm{~m}$ on Fylla Bank Station 2, mid-June, 1961-2002.

of fish and shellfish in West Greenland, sea temperature, drift of larvae by surface currents, and stability of the water masses (oceanographic fronts) have been proposed (Pedersen and Rice, 2002). Variability in these factors is related in turn to the inflow of water from other parts of the North Atlantic, which is strongly related to NAO variations. The individual strengths of the East Greenland Current and the Irminger Current have a dominating effect on the physical environment of the shelf areas around southern Greenland.

Based on changes in hydrographic observations, the ocean transport of salt and heat towards West Greenland appears to have decreased drastically after 1970. This occurred at the same time as the reduced heat flux into the ocean from the atmosphere. These climate changes seem to have had a negative effect on the recruitment success of the West Greenland cod stock, and a number of other boreal fish stocks, and a positive effect on the production of northern shrimp and Greenland halibut.

The drastic reduction (almost disappearance) in the West Greenland cod fishery is believed to have two causes:

- Reduction in the West Greenland spawning stock. The number of cod recruited at age 3 years have been documented to be significantly correlated with the spawning stock biomass and June water temperature on top of Fylla Bank (Hansen and Buch, 1986; Hovgård and Buch, 1990). Both factors positively affected the number of offspring and explained $51 \%$ of the observed variation in recruitment (Rätz et al., 1999).
- Reduced inflow of cod larvae from Icelandic spawning grounds. The inflow of cod larvae occurred almost every year in the 1950s and early-1960s, (Fig. 2 in Hansen and Buch, 1986) but since then has been negligible except for the 1973 and 1984 year-classes.

Changes in the thermal regime can have a considerable impact on the abundance of groundfish and pandalid shrimps (Anderson 2000; Koeller, 2000; Stein, 2000). In the summer of 1982, cod larvae were abundant in West Greenland, but the following extremely cold winter was assumed to led to a dramatic reduction in this year-class (Pedersen and Smidt, 2000).

Northern shrimp prefer relatively cold temperatures in the range of $1-6^{\circ} \mathrm{C}$ and their larvae are less vulnerable to low temperatures compared to cod (Shumway et al., 1985). This may partly explain the positive reaction of the West Greenland shrimp stock to the changed climatic conditions. However, the shift in the underlying marine ecosystem at West Greenland may have been amplified by the declining cod stock due to a release in predation pressure on e.g. sandeel and northern shrimp (Koeller, 2000; Lilly et al, 2000). Additionally, by-catches in the steady growing fishery for northern shrimp during the last part of the $20^{\text {th }}$ century may have played a role in reducing and keeping the mean trophic level low (Kingsley et al. MS 1999; Pauly et al., 2001).

The observed increase in the shrimp biomass during recent years is related to both increasing growth (decrease in mean length at sex change) and recruitment (Carlsson 

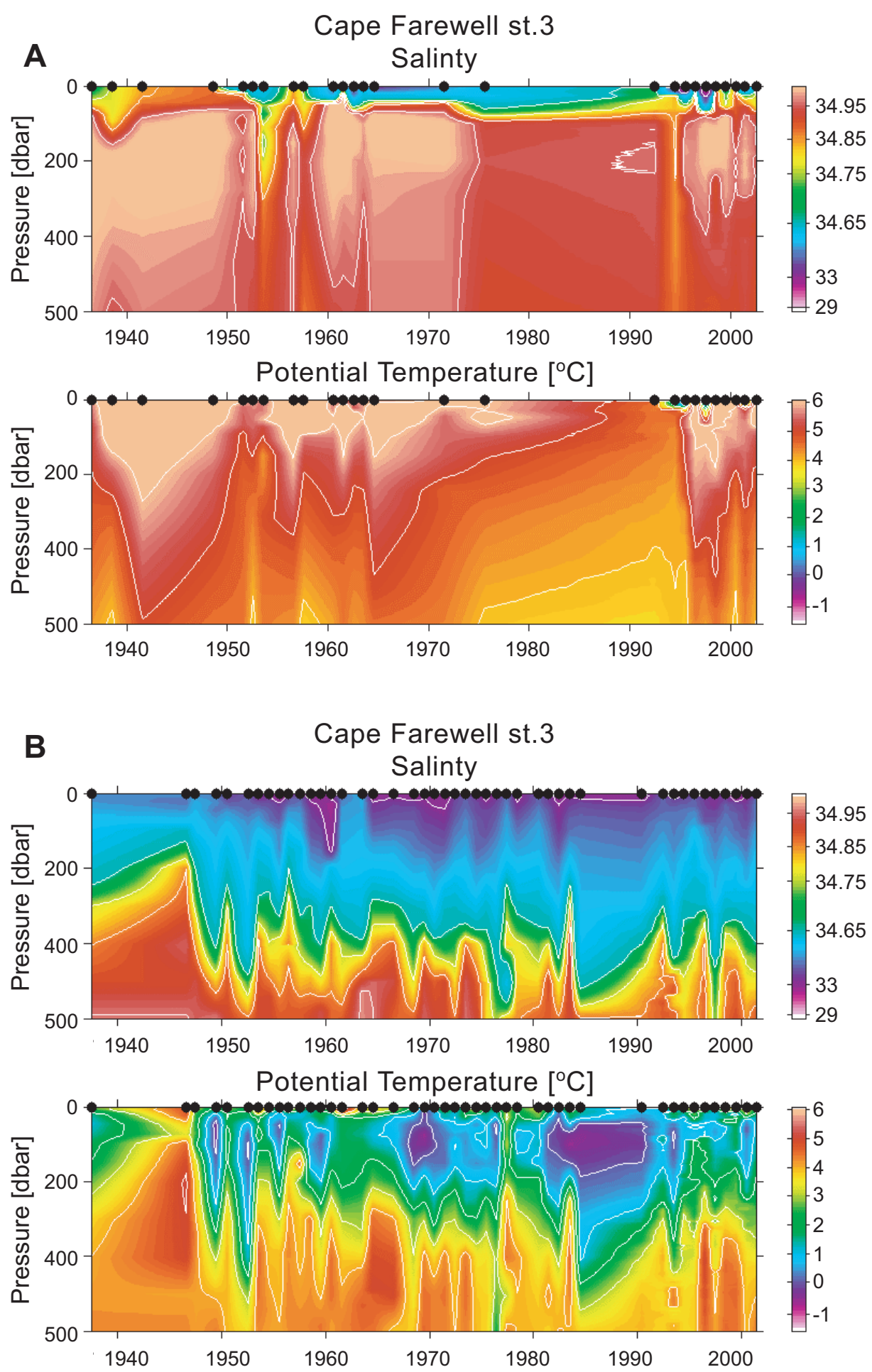

Fig 13. Time series of summer (June and July) salinity and temperature at (a) Cape Farewell Station 3 and (b) Fylla Bank Station 4 (see Fig. 1 for locations).

and Kanneworff, MS 1999; Siegstad, 2000). The shrimp recruitment indices (number of juvenile shrimp) show a steep increasing trend from 1997 to 2000, which is a good prospect for the shrimp fishery (Fig. 5a). This positive development is believed to be related to the favourable temperature conditions observed off West Greenland 
during this period, especially the increased inflow of warm Irminger Water (Fig. 14) to the area.

The relative cold period from the late-1980s to 1995 , when temperatures decreased below the temperature preference of shrimp $\left(3-4^{\circ} \mathrm{C}\right)$, seemed to have resulted in a southern migration of the shrimp stock and the fishery. The warming trend from 1995 to 2000 towards preferred temperatures seems to have favoured growth and recruitment of northern shrimp, thereby leading to an extraordinary increase in the shrimp biomass since the late-1990s.

Extensive ice cover in cold years contributes positively to the survival of larvae and juveniles in the same year and the effect can be detected in the CPUE several years later (the mean age of shrimp in the catch is about 6 years) (Parsons and Colbourne, 2000). A recent study by Ramseier et al. (2000) showed that the extent of localized sedimentation of particulate organic carbon (POC) can be derived from information about ice cover. POC likely plays an important role as food supply for shrimp, and it is possible that the explanation of the functional relationship is related more to nutrient supply than temperature-related phenomena. According to Parsons and Colbourne (2000) this would help explain the apparent inconsistencies between in situ observations, which suggest "cold conditions" are favourable for shrimp, and laboratory studies, which indicate that larval growth and survival are enhanced at higher temperatures.

\section{Summary}

- The Greenland economy, which was formerly highly dependent on a rich cod fishery, is today almost entirely dependent on the Greenland shrimp stock.
- The Greenland climate since 1970 has been considerably colder than during the 1920-70 period, which can be related to a shift in the NAO index from negative to positive values.

- The redistribution of the atmospheric pressure fields has altered the surface currents of the North Atlantic, resulting in the reduction of the inflow of heat, salt and cod larvae to the West Greenland area.

- While there are good correlations between the climate changes and the observed shift in the marine ecosystem off West Greenland, scientific investigations to understand the ecological, chemical and physical processes behind the changes in the marine ecosystem are required.

- The increase in the West Greenland shrimp stock biomass is most likely not solely attributable to the changes in climate. The near disappearance of the cod stock will have reduced shrimp predation by this species. Also by-catches in the shrimp fishery would contribute to keeping the predation pressure low.

- The close relationship between climate variability and the marine ecosystem off West Greenland strongly support the incorporation of effects of environmental fluctuations in prediction models for fish stock recruitment and the assessment of the fisheries resources. This will, however, require increased research in process studies that seek to understand the processes linking fisheries recruitment to environmental factors. Such efforts must include the development of coupled ocean and ecological models, not only to increase our understanding but also to make realistic forecasts of the ecosystem changes for use in

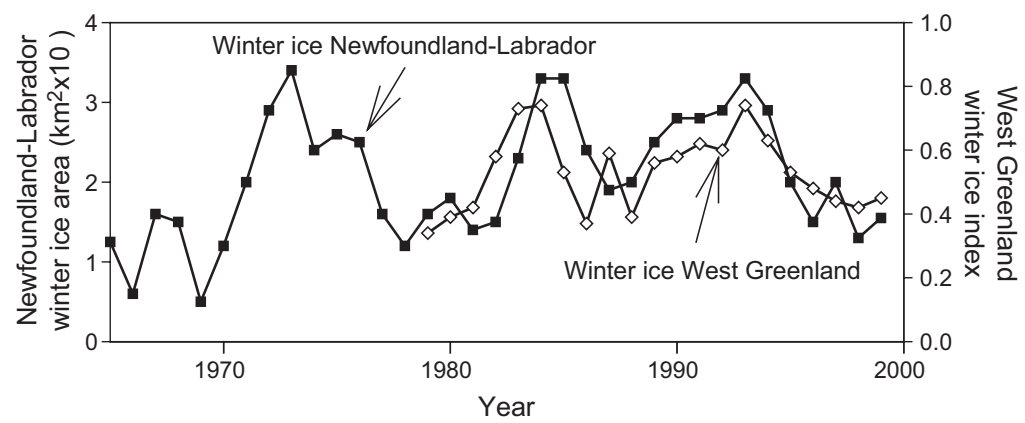

Fig. 14. Area of winter (January-March) ice cover $\left(\mathrm{km}^{2}\right)$ off NewfoundlandLabrador, 1963-99 from Drinkwater et al. (MS 2000) and area index of winter (January-Febuary) ice cover "Westice" off West Greenland $\left(62^{\circ} \mathrm{N}-70^{\circ} \mathrm{N}\right)$ from Leif Toudal Pedersen, Danish Technical University. 
fisheries assessment work. Models of ecosystem developments under changing climatic conditions should be considered in fishery assessments in the future and they should lead to better planning for the Greenland society.

\section{Acknowledgements}

We thank Phil Jones for providing old pressure data and updating the time-series for the Azores. We also thank two anonymous referees for corrections and suggestions to improve this paper. During this work S.A.P. was funded by the Danish National Research Council project no. 9803018, and M.H.R. was funded by the Nordic Council of Ministers as part of "West-Nordic Ocean Climate Research Programme".

\section{References}

ANDERSON, P. J. 2000. Pandalid shrimp as indicators of ecosystem regime shift. J.Northw. Atl. Fish. Sci., 27: $1-10$.

ANONYMOUS. MS 2000. Report of the North-Western Working Group. ICES C.M. Doc., No. Assess: 15, 328 p.

BARNETT, T. P. 1985. Variations in near-global sea level pressure. J. Atmos. Sci., 42: 478-501

BELKIN, I. M., S. LEVITUS, J. ANTONOV, and S.-Aa. MALMBERG. 1998. "Great Salinity Anomalies" in the North Atlantic. Progr. Oceanogr., 41: 1-68.

BLINDHEIM, J., V. BOROVKOV, B. HANSEN, S.-Aa MALMBERG, B. TURRELL, and S. ØSTERHUS. 2000. Upper layer cooling and freshening in the Norwegian Sea in relation to atmospheric forcing. Deep-Sea Res. I, 47: 655-680.

BUCH, E. 2000a. A monograph on the physical oceanography of the Greenland waters. Danish Meteorological Institute Scientific Report, 00-12, 405 p.

2000b. Air-sea-ice conditions off southwest Greenland, 1981-97. J. Northw. Atl. Fish. Sci., 26: 1-14.

BUCH, E., S.-AA. HORSTED, and H. HOVGÅRD. 1994. Fluctuations in the occurrence of cod in Greenland waters and their possible causes. ICES Mar. Sci. Symp., 198: $158-174$.

CARLSSON, D. M., and P. KANNEWORFF. MS 1999. Bottom temperatures and possible effect on growth and size at sex reversal of northern shrimp in West Greenland. NAFO SCR Doc., No. 110, Serial No. N4190, 7 p.

MS 2000. Stratified-random trawl survey for northern shrimp (Pandalus borealis) in NAFO Subareas 0+1, in 2000. NAFO SCR Doc., No. 78, Serial No. N4335, 27 p.

DICKSON, R. R., K. R. BRIFFA, and T. J. OSBORN. 1994. Cod and climate: the spatial and temporal context. ICES Mar. Sci. Symp., 198: 280-286.

DICKSON, R. R., J. R. N. LAZIER, J. MEINCKE, P. RHINES, and J. SWIFT. 1996. Long-term coordinated changes in the convective activity of the North Atlantic. Progr. Oceanogr.,
38: $241-295$.

DICKSON, R. R., J. MEINCKE, S.-Aa. MALMBERG, and A. J. LEE. 1988. The "Great Salinity Anomaly" in the northern North Atlantic 1968-1982. Prog. Oceanog., 20: 103-151.

DICKSON, R. R., T. J. OSBORN, J. W. HURRELL, J. MEINCKE, J. BLINDHEIM, B. ÄDLANDSVIK, T. VINJE, G. ALEKSEEV, and W. MASLOWSKI. 2000. The Arctic Ocean response to the North Atlantic Oscillation. J. Clim., 13: 2 671-2 696.

DRINKWATER K. F., E. COLBOURNE, and D. GILBERT. MS 2000. Overview of environmental conditions in the Northwest Atlantic in 1999. NAFO SCR Doc., No. 21, Serial No. N4250, 89 p.

HAMILTON, L., P. LYSTER, and O. OTTERSTAD. 2000. Social change, ecology and climate in 20th-century Greenland. Clim. Change, 47: 193-211.

HANSEN, H., and E. BUCH. 1986. Prediction of yearclass strength of Atlantic cod (Gadus morhua) off West Greenland. NAFO Sci. Coun. Studies, 10: 7-11.

HORSTED, S. A. 2000. A review of the cod fisheries at Greenland, 1910-1995. J. Northw. Atl. Fish. Sci., 28: $1-109$.

HOVGÅRD, H., and E. BUCH. 1990. Fluctuation in the cod biomass of the West Greenland Ecosystem in relation to climate. K. Sherman, L. M. Alexander, and B. D. Gold (eds.). Large Marine Ecosystems: Patterns, Processes, and Yields. AAAS Press, Washington, p. 36-43.

HURRELL, J. W. 1995. Decadal trends in the North Atlantic Oscillation: regional temperatures and precipitation. Sci., 269: $676-679$.

HURRELL, J. W., and H. VAN LOON. 1997. Decadal variations in climate associated with the North Atlantic Oscillation. Clim. Change, 36: 301-326.

HVINGEL, C. MS 2000. The Greenlandic fishery for northern shrimp (Pandalus borealis) off West Greenland, 19702000. NAFO SCR Doc., No. 81, Serial No. N4338, 27 p.

ICES. MS 1996. Report of the North-Western Working Group. ICES C.M. Doc., No. Assess: 15, 377 p.

MS 2000. The 1999/2000 ICES annual ocean climate status summary. Prepared by the Working Group on Oceanic Hydrography. Editor: Bill Turrell. (www.ices. $\mathrm{dk} /$ status/clim9900/).

MS 2001. The 2000/2001 ICES annual ocean climate status summary. Prepared by the Working Group on Oceanic Hydrography. Editors: Bill Turrell and N. Penny Holliday. (www.ices.dk/status/clim0001/).

MS 2002. The 2001/2002 ICES annual ocean climate status summary. Prepared by the Working Group on Oceanic Hydrography. Editors: Bill Turrell and N. Penny Holliday. (www.ices.dk/status/clim0102/).

JENSEN, A. S. 1939. Concerning a change of climate during recent decades in the Arctic and subarctic regions, from Greenland in west to Eurasia in the east, and contemporary biological and geophysical changes. Det Kgl. Danske Videnskabernes Selskab. Biologiske Meddelelser, XIV, 8. København. (Munksgaard. 75 p. with 2 charts).

JONES, P. D., T. JONSSON, and D. WHEELER. 1997. Extension of the North Atlantic Oscillation using instrumental pressure 
observations from Gibraltar and south-west Iceland. Int. J. Climatol., 17: 1433-1450.

KANNEWORFF, P. MS 2000. Occurrence of Pandalus montagui in trawl survey samples from NAFO Subarea $0+1$. NAFO SCR Doc., No. 77, Serial No. N4334, 6 p.

KINGSLEY, M. C. S., P. KANNEWORFF, and D. M. CARLSSON. MS 1999. By-catches of fish in the West Greenland shrimp survey: an initial analysis. NAFO SCR Doc., No. 111, Serial No. N4191, 7 p.

KOELLER, P. A., 2000. Relative importance of abiotic and biotic factors to the management of the northern shrimp (Pandalus borealis) fishery on the Scotian Shelf. J. Northw. Atl. Fish. Sci., 27: 21-33.

LILLY, G. R., D. G. PARSONS, and D.W. KULKA. 2000. Was the increase in shrimp biomass on the northeast Newfoundland Shelf a consequence of a release in predation pressure from cod? J.Northw. Atl. Fish. Sci., 27: 45-61.

MALMBERG, S.-Aa. 1985. The water masses between Iceland and Greenland. Rit. Fiskideildar, 9: 127-140.

MORTENSEN, J. and H. VALDIMARSSON. MS 1999. Thermohaline changes in the Irminger Sea. ICES C.M. Doc., No. L:16.

MOSES, T., G. N KILADIS, H. F. DIAZ, and R. G. BARRY. 1987. Characteristics and frequency reversals in mean sea level pressure in the North Atlantic sector and their relationships to long-term temperature trends. J. Climatol., 7: $13-30$.

PARKER, D. E., and C. K. FOLLAND. 1988. The nature of climatic variability. Met. Mag., 117: 201-210.

PARSONS, D. G., and E. B. COLBOURNE. 2000. Forecasting fishery performance for northern shrimp (Pandalus borealis) on the Labrador Shelf (NAFO Divisions 2HJ). J. Northw. Atl. Fish. Sci., 27: 11-20.

PAULY, D., M. L. PALOMAREWS, R. FROESE, P. SA-A., M. VAKILY, D. PREIKSHOT, and S. WALLACE. 2001. Fishing down Canadian aquatic food webs. Can. J. Fish. Aquat. Sci., 58: 51-62.

PEDERSEN, S.A,. and P. KANNEWORFF. 1995. Fish on the West Greenland shrimp grounds, 1988-1992. ICES J. Mar. Sci., 52: 165-182.

PEDERSEN, S.A., and J. RICE. 2002. Dynamics of fish larvae, zooplankton, and hydrographical characteristics in the West Greenland Large Marine Ecosystem 1950-1984. K. S. Shermann, and H.-R. Skjoldal (eds). Large Marine Ecosystems of the North Atlantic: Changing States and Sustainability. Elsevier Science, Amsterdam, The Netherlands, p.151-193.

PEDERSEN, S.A., and E.L.B. SMIDT. 2000. Zooplankton distribution and abundance in West Greenland waters, 1950-1984. J. Northw. Atl. Fish. Sci., 26: 45-102.

PEDERSEN, S.A,. and D. ZELLER. 2001. A mass balance model for the West Greenland marine ecosystem. S. Guenette, V. Christensen. and D. Pauly (eds). Fisheries Impacts on North Atlantic Ecosystems: Models and Analyses. Fisheries Centre Research Reports, 9: 111-127.

RAMSEIER, R.O., C. GARRITY, D.G. PARSONS, and P. KOELLER. 2000. Influence of particle organic carbon sedimentation within the seasonal sea-ice regime on the catch distribution of northern shrimp (Pandalus borealis). J. Northw. Atl. Fish. Sci., 27: 35-44.

RÄTZ, H.-J. 1999. Structures and changes of the demersal fish assemblage off Greenland, 1982-96. NAFO Sci. Coun. Studies, 32: 1-15.

RÄTZ, H.-J., and C. STRANSKY. MS 1999. Assessment of redfish (Sebastes marinus, S. mentella) in NAFO Subarea 1 and ICES Div. XIVb based on survey indices, 1982-98. NAFO SCR. Doc., No. 20, Serial No. N4070, 22 p.

RÄTZ, H.-J., M. STEIN, and J. LLORET. 1999. Variation in growth and recruitment of Atlantic cod (Gadus morhua) off Greenland during the second half of the twentieth century. J. Northw. Atl. Fish. Sci., 25: 161-170.

RIGET, F., and J. ENGELSTOFT. 1998. Size-at-age of cod (Gadus morhua) off West Greenland, 1952-92. NAFO Sci. Coun. Studies, 31: 1-12.

SEAGER, R., D. S. BATTISTI, J. YIN, N. GORDON, N. NAIK, A. C. CLEMENT, and M. A. CANE. 2003. Is the Gulf Stream responsible for Europe's mild winters? Quarterly Journal of the Royal Meteorological Society, 128: 2 563-2 586.

SHUMWAY, S.E., H. C. PERKINS, D. F. SHICK, and A. P. STICKNEY. 1985. Synopsis of biological data on the pink shrimp, Pandalus borealis Krøyer, 1838. NOAA Technical Report, NMFS 30 (FAO Fisheries Synopsis No. 144), $57 \mathrm{p}$.

SIEGSTAND, H. MS 2000. Preliminary assessment of shrimp (Pandalus borealis) in Davis Strait, 2000 (Subareas 0+1). NAFO SCR Doc., No. 84, Serial No. N4341, 22 p.

STEIN, M. 2000. Hydrographic and atmospheric conditions off East Greenland - their potential effect on the distribution of shrimp (Pandalus borealis). J. Northw. Atl. Fish. Sci., 27: $63-67$.

VAN LOON, H., and J. C. ROGERS. 1978. The seesaw in winter temperatures between Greenland and Northern Europe. Part I: general description. Mon. Wea. Rev., 106: 296-310.

VAN LOON, H., and J. WILLIAMS. 1976. The connection between trends of mean temperature and circulation at the surface: Part I. winter. Mon. Wea. Rev., 104: 365-380. 